\title{
Expression of peroxisome proliferator-activated receptors in lean and obese Zucker rats
}

\author{
Agnieszka Gorla-Bajszczak ${ }^{1}$, Catherine Siegrist-Kaiser ${ }^{1}$, Olivier Boss ${ }^{2}$, Albert G Burger ${ }^{1}$ \\ and Christoph A Meier ${ }^{1,3}$ \\ ${ }^{1}$ Division d'Endocrinologie et Diabétologie, ${ }^{2}$ Biochimie Médicale, Faculté de Médecine and ${ }^{3}$ Clinique de Médecine II, Département de Médecine Interne, \\ Hôpital Cantonal Universitaire de Genève, CH-1211 Geneva, Switzerland \\ (Correspondence should be addressed to C A Meier, Division d'Endocrinologie et Diabétologie, Hôpital Cantonal Universitaire, 24 rue Micheli-du-Crest, \\ CH-1211 Geneva 14, Switzerland; Email: cameier@genet.ch)
}

\begin{abstract}
Objective: Examination of the pattern of expression of peroxisome proliferator-activated receptor (PPAR) isoforms $\alpha$ and $\gamma$ in a model of obesity.

Design: Examination of adipose tissue and primary adipocyte cultures from lean and obese Zucker rats at different ages ( 28 days and 12 weeks).

Methods: mRNA levels were measured by RNase protection assay.

Results: The highest levels of PPAR $\alpha$ and $\gamma$ mRNA were present in brown adipose tissue (BAT), followed by liver and white adipose tissue (WAT) for the $\alpha$ and $\gamma$ subtypes, respectively, at both ages examined. PPAR $\alpha$ was expressed 100-fold higher in BAT compared with WAT, and PPAR $\gamma$ mRNA levels were 2 -fold higher in the WAT of obese compared with lean rats. PPAR $\alpha$ and $\gamma$ expression was minimal in m. soleus, although higher levels of PPAR $\gamma$ were found in the diaphragm. In marked contrast to the findings in vivo, virtually no PPAR $\alpha$ mRNA could be detected in BAT cultures differentiated in vitro. Conclusion: PPAR $\alpha$ and $\gamma$ are most highly expressed in BAT in vivo. However, PPAR $\alpha$ is undetectable in brown adipose cells in vitro, suggesting that the expression of this receptor is induced by some external stimuli. In addition, the expression of PPAR $\gamma$ was increased in WAT from young obese animals, compatible with an early adaptive phenomenon. Finally, the presence of PPAR $\gamma$ mRNA is detectable only in particular muscles, such as the diaphragm, suggesting the possibility of an influence of fiber type on its expression, although exercise did not influence the expression of PPAR $\gamma$ in other skeletal muscles.
\end{abstract}

European Journal of Endocrinology 142 71-78

\section{Introduction}

The peroxisome proliferator-activated receptors (PPARs) are ligand-activated transcription factors of the steroid/ thyroid hormone nuclear receptor superfamily (1). These receptors are important in the regulation of the expression of genes involved in lipid and glucose homeostasis, as well as adipocyte differentiation and the immune response. Three different genes encode for the known PPAR isoforms $\alpha, \beta / \delta$ and $\gamma$, which are differentially expressed and exhibit distinct functional and molecular properties. The PPAR $\alpha$ isoform is predominantly present in liver, and one of its main functions appears to be the regulation of key enzymes and proteins involved in the $\beta$-oxidation of fatty acids, lipoprotein synthesis and the P450 oxidative pathway, the latter being important for the catabolism of xenobiotics and mediators of inflammation, such as leukotriene B4 (LTB4) $(2,3)$. $\operatorname{PPAR} \alpha$ is physiologically activated mainly by fatty acids and their derivatives, such as arachidonic acid and LTB4, while it is also the main pharmacological target for the hypolipidemic drugs of the group of the fibrates, such as clofibrate (4). The PPAR $\gamma$ isoform, in contrast, is expressed at high levels in adipose tissue and the immune system, where it is activated by fatty acid derivatives and certain prostaglandins (PGs), such as 15-deoxy- $\Delta^{12,14}$-PGJ2. Pharmacologically, PPAR $\gamma$ appears to be the major target for the antidiabetic thiazolidinediones, as well as for non-steroidal antiinflammatory drugs, at least at high doses (5). This latter PPAR isoform is important for inducing adipocyte differentiation, and it has anti-inflammatory properties in activated macrophages. In addition, it contributes to the insulin sensitivity of muscle and adipose tissue by some as yet undefined molecular pathway (6).

Given the role of PPAR $\alpha$ and $\gamma$ in regulating triglyceride homeostasis and glucose sensitivity, we examined the expression pattern of the PPAR $\alpha$ and $\gamma$ isoforms in the relevant target tissues (adipose tissue, liver, and muscle) of lean $(F A / f a)$ and obese $(f a / f a)$ Zucker rats, which harbor a functionally inactivating mutation in the extracellular domain of the leptin receptor, 
resulting in obesity and insulin resistance (7). In order to examine the possible adaptation of PPAR mRNA levels during the development of the obese and diabetic phenotype, we examined the animals in a young (aged 28 days) and a fully obese (aged 12 weeks) state. In addition, the effect of chronic exercise on the expression of PPAR $\gamma$ in skeletal muscle was examined in the OFA rat strain. Finally, we examined the expression levels of $\operatorname{PPAR} \alpha$ and $\gamma$ in primary cultures of white and brown adipose tissue (WAT and BAT, respectively) from Zucker rats, which are a frequently used model for studying adipocyte biology.

\section{Materials and methods}

\section{Animals}

Lean $(F A / f a)$ and obese $(f a / f a)$ male Zucker rats had free access to water and a standard diet (Provimi Lacta SA, Cossonay, Switzerland). Twenty-eight-day-old freshly weaned (28d) and 12-week-old adult $(12 \mathrm{w})$ rats were used for this study. For the RNA studies the animals were killed by decapitation and the tissues snap frozen in liquid nitrogen.

The exercise studies were performed as described previously (8). Briefly, 24 male pathogen-free OFA rats (110 g body weight) were housed in a temperaturecontrolled room $\left(22 \pm 2{ }^{\circ} \mathrm{C}\right)$ with a light-dark cycle $(12: 12 \mathrm{~h})$ and maintained on a diet of water and Purina laboratory chow. After 1 week, animals were randomly assigned to either a sedentary group (number of rats, $n=5)$ or a training group $(n=5)$. During the treadmill training program, rats initially ran for $10 \mathrm{~min}$ at $30 \mathrm{~m} / \mathrm{min}$ on a $10 \%$ incline. The duration of exercise was then progressively increased by $5 \mathrm{~min}$ per day so that, by the end of the fourth week, the animals were running for $90 \mathrm{~min}$ at $30 \mathrm{~m} / \mathrm{min}$ up a $10 \%$ slope, 5 days per week. The rats were maintained at this level of training for another 4 weeks.

\section{RNA preparation}

For RNA extraction from organs, the frozen tissues were homogenized in $4 \mathrm{~mol} / \mathrm{l}$ guanidine isothiocyanate, $5 \mathrm{mmol} / \mathrm{l}$ sodium citrate, $0.5 \%$ sarcosyl and $0.1 \mathrm{~mol} / \mathrm{l}$ $\beta$-mercaptoethanol (GTC), and total RNA was prepared by the guanidinium/CsCl step-gradient method.

For RNA extraction from cell cultures, the cells were washed once with phosphate-buffered saline, scraped directly in GTC solution, and homogenized through repeated drawing of the lysate through a $20-\mathrm{G}$ needle.

\section{RNase protection assay}

The pKS+/PPAR $\alpha$ plasmid was digested by TaqI and the 717-base fragment of interest contained the T7 promoter sequence and the last 287 nucleotides of the $\operatorname{rPPAR} \alpha$ insert. The $\mathrm{pKS}+/ \mathrm{PPAR} \gamma$ plasmid was digested with EcoRI and HindIII, and the 403-base pair fragment contained nucleotides 188-590 of PPAR $\gamma$ cDNA linked to the T7 promoter. Similarly, the pKS+/L27 plasmid containing the cDNA for the large ribosomal $27 \mathrm{kDa}$ protein L27 was linearized with EcoRI. From the isolated fragments described above, antisense $\left(\alpha{ }^{3}{ }^{32} \mathrm{P}\right) \mathrm{UTP}-$ labeled riboprobes were synthesized using T7 RNA polymerase using a $1: 1$ ratio of $\left(\alpha-{ }^{32} \mathrm{P}\right)$ UTP to cold UTP for the PPAR probes and a ratio of $1: 29$ for the L27 riboprobe to allow for equal exposure times as described previously (9). Specific activities of the riboprobes were typically around $5 \times 10^{7}$ c.p.m./ $\mu$ g for L27 probe and around $2.5 \times 10^{8}$ c.p.m. $/ \mu$ g for the PPAR $\alpha$ and PPAR $\gamma$ probes.

The RNase protection assay was carried out with minor modifications as described previously (10). Briefly, total RNA $(20 \mu \mathrm{g}$ for muscle, $10 \mu \mathrm{g}$ for all other organs) was hybridized to a mixture of $10 \mathrm{ng}$ of L27 riboprobe and either 1 ng of $\operatorname{PPAR} \alpha$ or PPAR $\gamma$ riboprobe. The saturating levels of different probes were previously established (9). Hybridization was performed at $42{ }^{\circ} \mathrm{C}$, and digestion with RNase Ti alone (Gibco) was carried out at $30^{\circ} \mathrm{C}$ for $90 \mathrm{~min}$. Protected fragments were separated on $6 \%$ denaturing polyacrylamide sequencing gels. The gels were dried and exposed on a PhosphorImager screen (Molecular Dynamics) for quantification before autoradiographs were obtained. All quantifications were done after the same exposure time. The protected fragments had an expected size of 287, 403 and 220 nucleotides for the $\operatorname{PPAR} \alpha, \operatorname{PPAR} \gamma$ and L27 probes, respectively. In some experiments two bands of somewhat different size were observed, corresponding to the presence of a slightly premature termination of riboprobe synthesis during in vitro transcription.

\section{Cell culture}

In order to obtain primary adipocyte cultures, 21- to 24-day-old lean $(F A / f a)$ or obese $(f a / f a)$ male rats were killed and interscapular BAT or periepididymal WAT was removed immediately, as described previously (11). BAT precursor cells were isolated, cultured and differentiated according to the method of Champigny et al. (12) with minor modifications. Cells were plated and cultivated for 1 day in DMEM/F12 medium supplemented with: $40 \mathrm{mmol} / \mathrm{l}$ sodium bicarbonate, $0.16 \mathrm{mmol} / \mathrm{l}$ biotin, $9 \mu \mathrm{mol} / \mathrm{l}$ pantothenic acid, $2.5 \mathrm{mmol} / \mathrm{l}$ glutamine, $16 \mathrm{mmol} / \mathrm{l}$ glucose, $30 \mathrm{mmol} / \mathrm{l}$ Hepes, $50 \mathrm{U} / \mathrm{ml}$ penicillin, $50 \mu \mathrm{g} / \mu \mathrm{l}$ streptomycin, $0.1 \mathrm{mmol} / \mathrm{l}$ ascorbate and $10 \%$ inactivated fetal calf serum (FCS). For the subsequent days cells were cultivated in the differentiation medium ITTD (13), containing: $100 \mathrm{nmol} / \mathrm{l}$ insulin, $10 \mu \mathrm{g} / \mathrm{ml}$ transferrin, $0.2 \mathrm{nmol} / \mathrm{l}$ triiodothyronine and $100 \mathrm{nmol} / \mathrm{l}$ dexamethasone. WAT cells generally took 7 days to differentiate as judged by the accumulation of lipid droplets, whereas BAT took about 11 days, as assessed 
A)

BA T

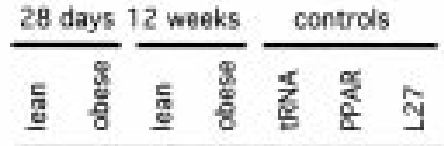

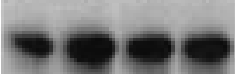

PPAPRis -

$\mathbf{L 2 7}$

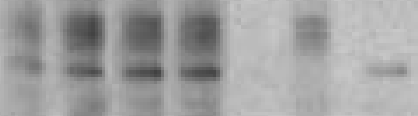

W A T

LIVER
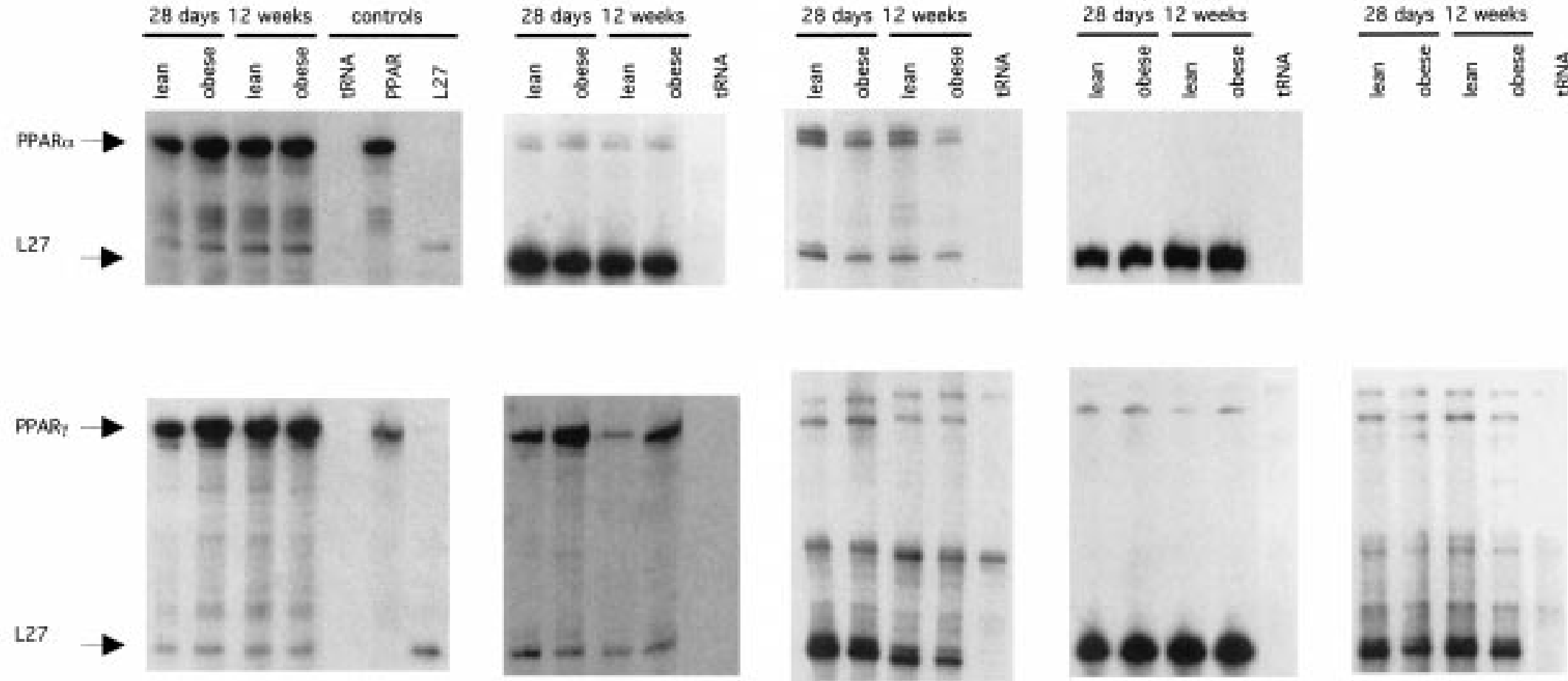

Figure 1 Comparative analysis of the mRNA levels of PPAR $\alpha$ and $\gamma$ in organs from lean ( $F A / f a)$ and obese (fa/fa) rats at the age of 28 days and 12 weeks. Total RNA ( $20 \mu \mathrm{g}$ for muscle, $10 \mu \mathrm{g}$ for all other organs) from the various organs was analysed by RNase protection assay using a riboprobe for either PPAR $\alpha$ (A) or PPAR $\gamma$ (B), together with the control probe L27. Expression was examined in lean and obese animals at 28 days (freshly weaned) and 12 weeks old. For each experimental point 3 animals were studied, except for the expression of PPAR $\gamma$ in WAT, where 4 (lean 28d) or 5 (obese 28d, lean and obese 12w) animals were used. Representative results from one animal of each group are shown (for quantification see Fig. 2). tRNA was used as a negative control, and riboprobes derived from the cDNAs for PPAR $\alpha$, PPAR $\gamma$ or L27 were used separately to confirm the relative migration of the various mRNAs when all probes were added together. 
morphologically and by the expression of high-levels of uncoupling protein-1. Before harvesting, the differentiated cells were treated for $24 \mathrm{~h}$ in ITTD medium with either vehicle, $50 \mu \mathrm{mol} / \mathrm{l}$ 5,8,11,14-eicosatetraynoic acid (ETYA), $1 \mu \mathrm{mol} / \mathrm{l}$ 8-hydroxy-5,8,11,14-eicosatetraenoic acid $(8(S)$ HETE, Cayman Chemicals) or 1 $\mu \mathrm{mol} / \mathrm{l}$ BRL49653.

\section{Statistical analysis}

All data were analyzed by the non-parametric KruskalWallis one-way analysis of variance with SYSTAT 8.0. The Mann-Whitney U test statistic for the comparison of two groups and a $P$ value $<0.05$ was considered significant.
A)

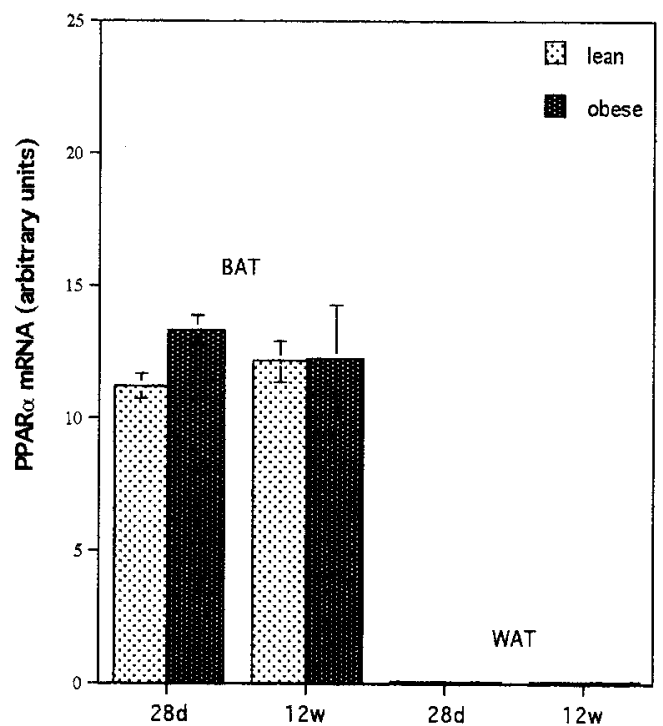

C)

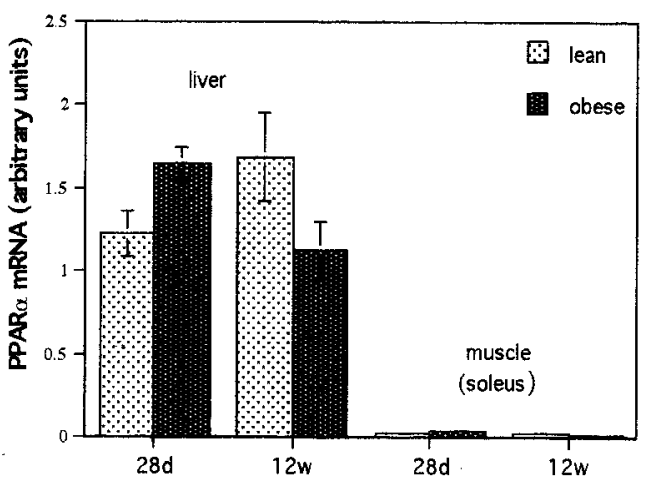

B)

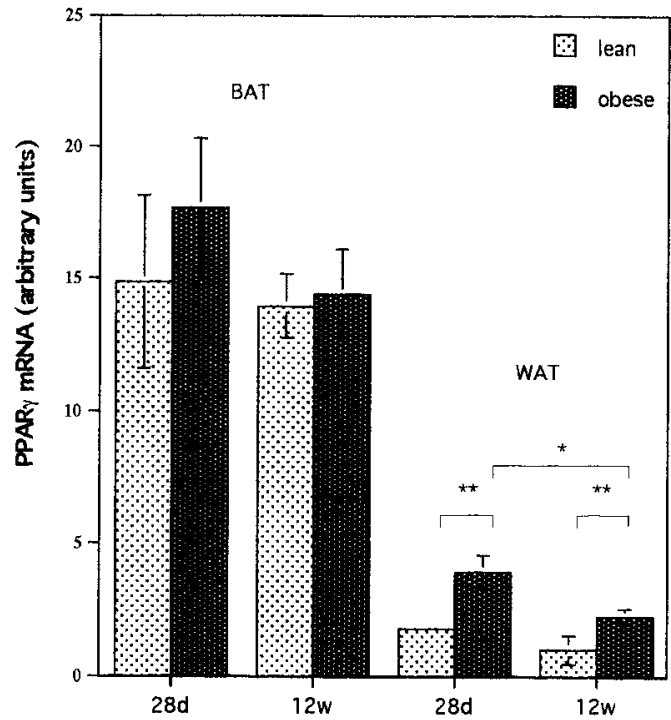

D)

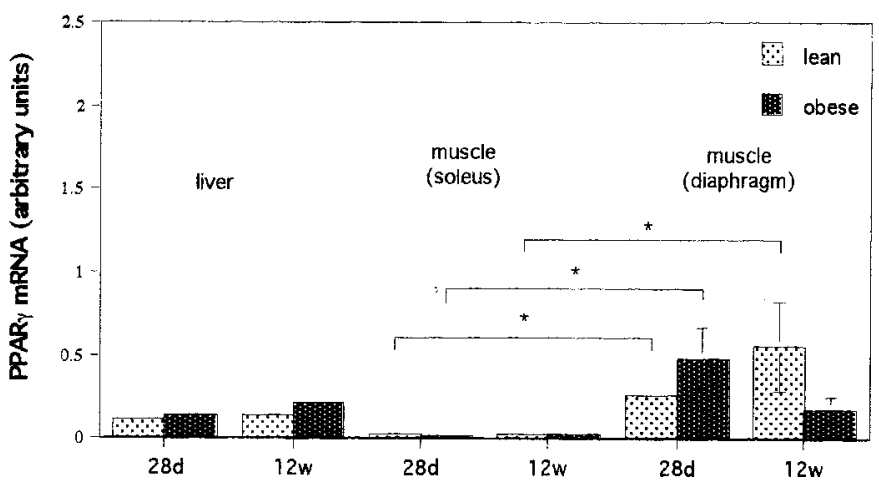

Figure 2 Quantification of the expression levels of PPAR $\alpha$ and $\gamma$ mRNA in various organs. The autoradiographs from all animals in each group described in Fig. 1 were quantified using a Phosphorlmager, and the data are represented as the ratio of PPAR transcript to the L27 RNA band (means \pm S.E.M., $n=3$ per group). Freshly weaned (28d) and 12-week-old (12w) lean ( FA/fa) and obese (fa/fa) Zucker rats were examined as described in the text. The levels of PPAR $\alpha$ and $\gamma$ in BAT and WAT are shown in A and B, respectively. The amounts of PPAR $\alpha$ and $\gamma$ transcripts present in liver and muscle are depicted in $\mathrm{C}$ and $\mathrm{D}$, respectively (note the difference in scale). The statistically significant differences in PPAR $\gamma$ levels between lean and obese rats (panel 2B), as well as between $m$. soleus and diaphragm (panel 2D) are indicated $\left({ }^{*} P<0.05,{ }^{* *} P<0.01\right)$. 


\section{Results}

Expression levels of PPAR $\alpha$ and $\gamma$ in BAT, WAT, liver and muscle of lean and obese Zucker rats at 28 days and 12 weeks of age

Using an RNase protection assay, the highest levels of $\operatorname{PPAR} \alpha$ and $\gamma$ were found in BAT (Figs 1 and 2). Intriguingly, PPAR $\alpha$ mRNA levels are 100-fold higher in BAT, compared with WAT, where it is minimally expressed (Figs 1A and 2A). Similarly, PPAR $\gamma$ transcript levels were about 10-fold higher in BAT relative to WAT. Age and the obese phenotype did not influence $\operatorname{PPAR} \alpha$ mRNA levels. In contrast, PPAR $\gamma$ levels were 2.3-fold higher in WAT from obese $f a / f a$ animals relative to the lean FA/fa controls (Figs $1 \mathrm{~B}$ and 2B) (28d: $1.7 \pm$ 0.18 vs $3.9 \pm 0.6, P<0.01)$. This difference remains comparable at 12 weeks $(P<0.01)$, although the absolute levels significantly decreased by $40 \%$ with age in the obese animals $(28 \mathrm{~d}$ vs $12 \mathrm{w}, P<0.05)$.

$\operatorname{PPAR} \alpha$ was also expressed in liver, as expected, but at much lower levels than in BAT (Figs 1A, 2A and 2C). No significant effect of age or the obese phenotype was observed in this organ. Hepatic PPAR $\gamma$ levels were found to be detectable, but very low (Fig. 2D). Expression levels of the mRNAs for PPAR $\alpha$ and $\gamma$ were generally at the detection limit in muscle, except for diaphragm, where significantly higher levels of PPAR $\gamma$ are present (lean animals (m. soleus vs diaphragm) at $28 \mathrm{~d}$ and $12 \mathrm{w}$, $P<0.05$; obese animals ( $m$. soleus vs diaphragm) at 28d, $P<0.05)$.

\section{Expression levels of PPAR $\gamma$ in skeletal and heart muscle of adult OFA rats before and after endurance training}

The effect of an 8 week endurance program on the expression of PPAR $\gamma$ mRNA levels in $\mathrm{m}$. soleus, $\mathrm{m}$. extensor digitorum longus (EDL) and the heart was examined by RNase protection assay. As shown in Fig. 3, the endurance training did not markedly alter PPAR $\gamma$ mRNA levels in these tissues, although a trend towards a reduction was found in the EDL and heart muscles.

\section{Expression of PPAR $\alpha$ and $\gamma$ in primary cultures of BAT and WAT}

In order to investigate the potential role of the selective expression of PPAR $\alpha$ in BAT, but not WAT, we examined the levels of these two PPAR isoforms in cultures derived from primary preadipocytes, which were differentiated in vitro into brown or white adipose cells. Surprisingly, while PPAR $\alpha$ was very abundant in BAT, there were extremely low mRNA levels in primary BAT cultures (Fig. 4A and B). In contrast, the levels of $\operatorname{PPAR} \gamma$ were similarly high in the brown adipose cultures and tissue.

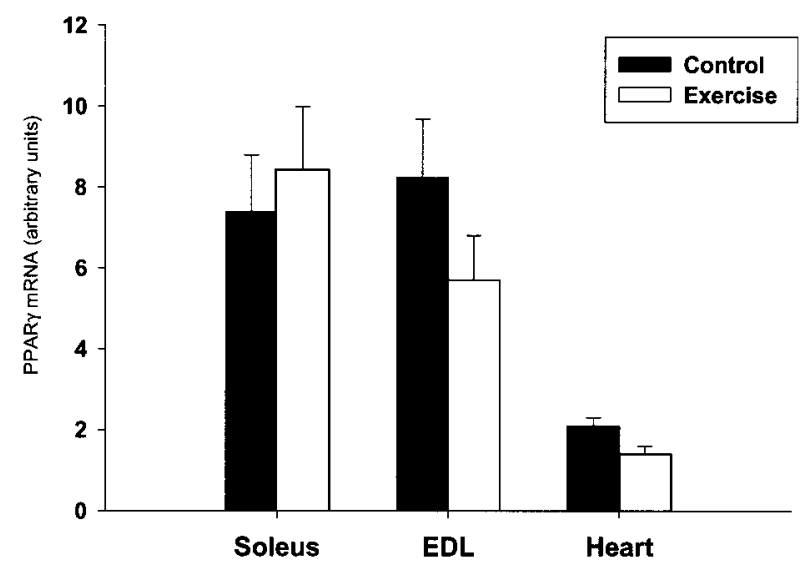

Figure 3 Expression of PPAR $\gamma$ in skeletal and heart muscle from control and endurance-trained OFA rats. OFA rats underwent endurance training for 8 weeks as described in Materials and methods. Total RNA $(10 \mu \mathrm{g})$ from heart or skeletal muscle (m. soleus and $\mathrm{m}$. extensor digitorum longus, EDL) was prepared and analysed by RNase protection assay for the presence of PPAR $\gamma$ mRNA as described above. The autoradiographs were quantified and the results normalized to the L27 internal standard (means \pm S.E.M., $n=5$ rats per group).

$\operatorname{PPAR} \alpha$ mRNA was at the detection limit in native and cultured WAT (Fig. 4B). However, the mRNA for PPAR $\gamma$ was well expressed in these cells exceeding the levels observed in WAT more than 8-fold (Fig. 4C). The same finding holds true for WAT from obese animals, although the difference was only 2.5 -fold. In contrast, no marked difference in the levels of PPAR $\gamma$ mRNA was present between cultures established from preadipocytes from genetically lean $(F A / f a)$ or obese $(f a / f a)$ rats. The phenotype of the cultured BAT was ascertained by verifying the expression of uncoupling protein-1 mRNA by Northern blotting (data not shown).

Since high levels of PPAR $\alpha$ were present in BAT in vivo, but not in primary cultures, we exposed the primary cultures of BAT to various PPAR $\alpha$ stimulators (ETYA, $8(S)$-HETE) and/or PPAR $\gamma$ (BRL49653), since PPAR $\alpha$ ligands (fibrates) were previously shown to induce the expression of their receptor in liver. However, none of the agents tested markedly induced $\operatorname{PPAR} \alpha$ expression (Fig. 4D).

\section{Discussion}

We have examined the expression of $\operatorname{PPAR} \alpha$ and $\gamma$ in various tissues of young (freshly weaned) and old lean $(F A / f a)$ or obese $(f a / f a)$ Zucker rats by means of an RNase protection assay. While our results demonstrate the expected expression of $\operatorname{PPAR} \alpha$ and $\gamma$ in liver and WAT, respectively, we found the highest levels of both isoforms in brown adipose tissue (BAT). In addition, PPAR $\gamma$ mRNA levels were significantly higher in white adipose tissue of the $f a / f a$ obese animals at 28 days and 12 weeks of age. PPAR $\gamma$ could also be detected in the muscle of 
A)

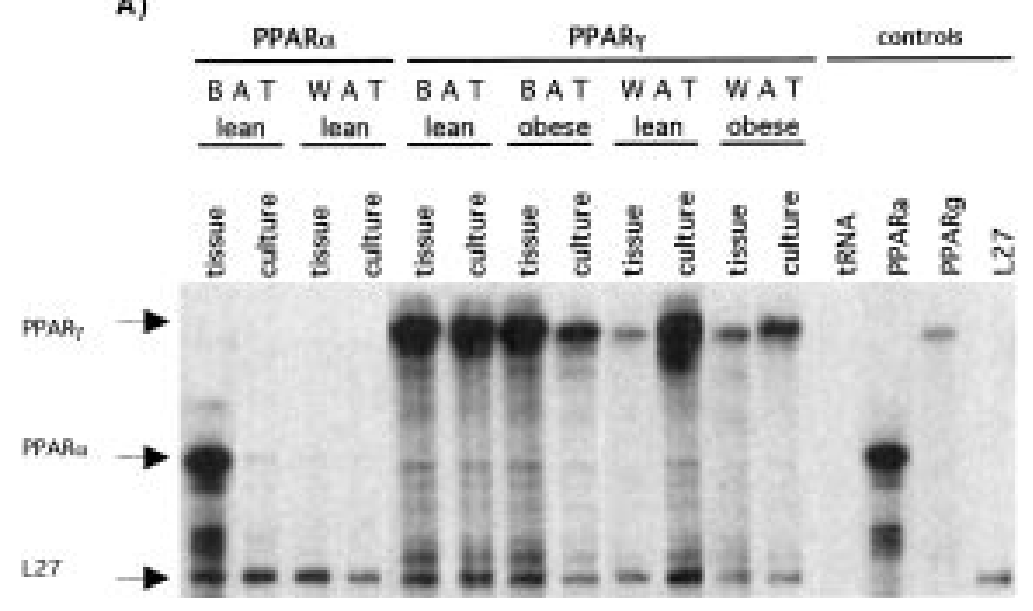

C)

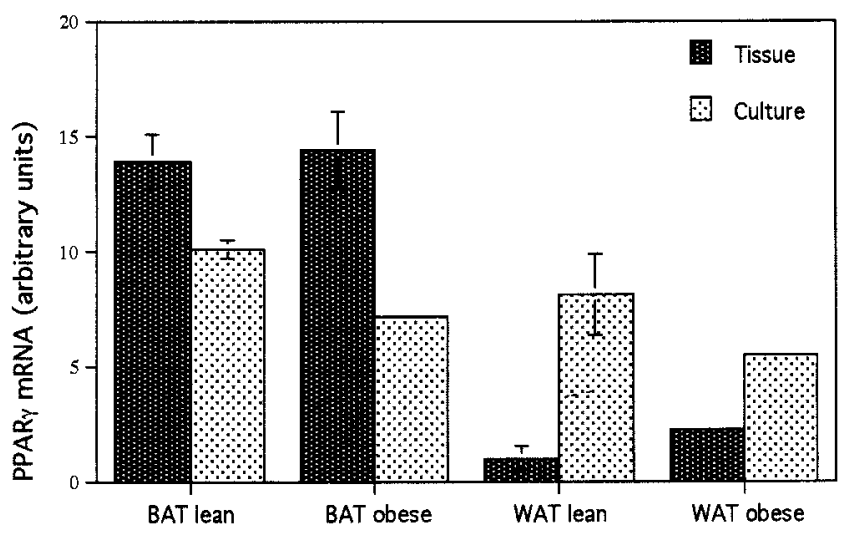

B)

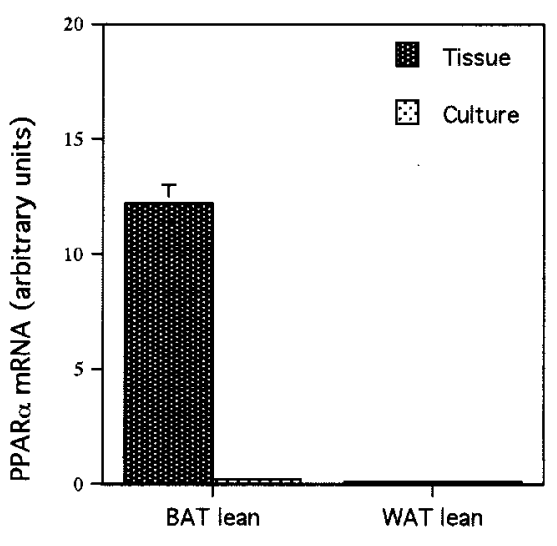

D)

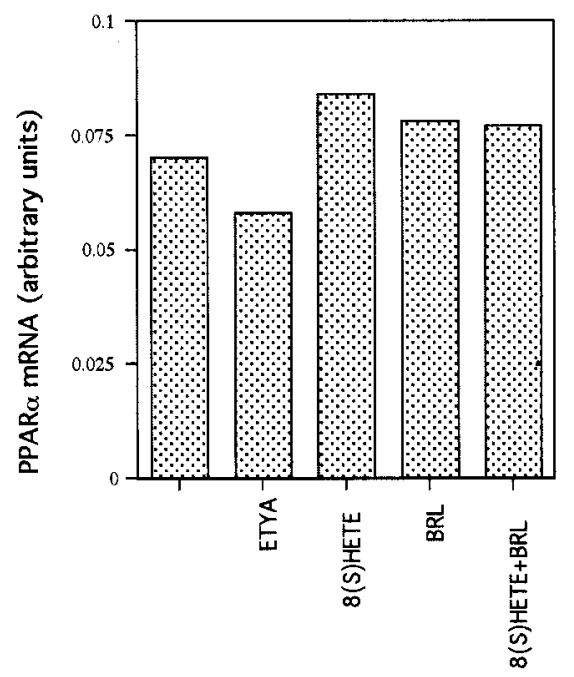

Figure 4 Expression of PPAR $\alpha$ and $\gamma$ in tissue samples and primary cultures of WAT and BAT. Total RNA (10 $\mu \mathrm{g})$ from BAT and WAT tissue samples or primary cultures was analysed by RNase protection assay for the presence of PPAR $\alpha$ or PPAR $\gamma$ mRNA as described in Materials and methods. For this experiment, fully differentiated primary cultures or tissue from 12-week-old lean or obese Zucker rats were used. The autoradiograph is shown in A, and the quantitated results for PPAR $\alpha$ and $\gamma$ (normalized for the L27 RNA band) in panels B and C, respectively (means \pm S.E.M., two independent experiments). The effect of peroxisome proliferators on expression levels of PPAR $\alpha$ in primary cultures of BAT derived from lean animals was examined by treating the cells for $24 \mathrm{~h}$ with $50 \mu \mathrm{mol} / / \mathrm{ETYA}, 1 \mu \mathrm{mol} / / \mathrm{l}(\mathrm{S}) \mathrm{HETE}$, $1 \mu \mathrm{mol} / \mathrm{l} \mathrm{BRL} 49653$ (BRL) or both $1 \mu \mathrm{mol} / \mathrm{l}$ 8(S)HETE and $1 \mu \mathrm{mol} / \mathrm{l} \mathrm{BRL49653} \mathrm{(D).}$

diaphragm, but was at the limit of detection in the soleus muscle. However, the $f a$ genotype or age did not affect the levels of PPAR $\gamma$ in this tissue. These observations raise several questions: (i) the role of PPAR $\alpha$ in BAT, and (ii) the relevance of the increased levels of PPAR $\gamma$ in the WAT of young (28d) $f a / f a$ animals, a finding that is reminiscent of some of the recent studies in overtly obese humans, and (iii) the possibility of a muscle-specific or activity-related expression pattern of $\operatorname{PPAR} \gamma$.

Since PPAR $\alpha$ is present at high levels in BAT, but only at very low levels in WAT, this isoform might be involved in the development and/or regulation of the metabolic functions of this tissue. This hypothesis appeared plausible, since activators of $\operatorname{PPAR} \alpha$ (e.g. fatty acids) are known to induce energy expenditure in rodents, and the promoter for uncoupling protein-1 was recently shown to contain a PPAR-binding site (14). In order to try to address this issue, we characterized in vitro differentiated brown adipose cells with regards to their expression of PPARs. In these cells, however, PPAR $\alpha$ was barely detectable, while PPAR $\gamma$ mRNA was highly abundant, suggesting that the high levels of PPAR $\alpha$ found in BAT in vivo reflect the presence of an exogenous 
inducer. This hypothesis is also in keeping with the absence of detectable amounts of $\operatorname{PPAR} \alpha$ mRNA in the T37i hibernoma cell line by Northern blot analysis (15) (M C Zennaro, personal communication).

The finding of increased levels of PPAR $\gamma$ in WAT, but not BAT, from young $f a / f a$ rats already at an age of $28 \mathrm{~d}$ is of interest. While some studies have reported an increase in PPAR $\gamma$ levels in the WAT of obese humans (16), this appears to be a depot-specific rather than a universal finding $(17,18)$. Similarly, increased levels of $\operatorname{PPAR} \gamma$ mRNA were described following toxigeneinduced obesity, but not in gold thioglucose or $o b / o b$ mice (19). However, these studies have focused on the assessment of PPAR $\gamma$ levels in the established obese phenotype. Our findings that the 28-day-old obese $f a / f a$ animals demonstrate increased expression of PPAR $\gamma$ mRNA are compatible with this being an early abnormality. However, since PPAR $\gamma$ levels are very similar in cultured white adipose cells from lean and obese animals, it seems likely that this alteration is adaptive to, rather than causative of the obese phenotype. In addition, the observation of a decrease in PPAR $\gamma$ levels approaching those of lean animals at 12 weeks of age is suggestive that this may be a transient adaptive phenomenon during early obesity, thereby explaining the variability in the reported human trials. A similar finding has recently been reported for WAT, where human omental fat expresses higher levels of PPAR $\gamma$ mRNA than peripheral subcutaneous adipose tissue. The cause for the increase in PPAR $\gamma$ levels in early obesity is a matter of speculation. Principally, this increased expression could reflect either a direct effect of hyperphagia, or be a consequence of the various hormonal changes of caloric excess, such as insulin resistance with hyperinsulinemia, hyperleptinemia or glucocorticoid excess.

In addition to the tissues discussed above, we were able to detect PPAR $\gamma$ mRNA at appreciable levels in the muscle of diaphragm, but virtually no transcripts were present in the soleus muscle. Although the possibility that this is due to the differential contamination with white adipocytes cannot be formally excluded, it is noteworthy that the diaphragm is an essentially isolated structure free of macroscopic WAT. Hence, together with the recent findings that the PPAR $\gamma$ ligand troglitazone can exert its insulin-sensitizing effect independent of adipose tissue, our data would suggest that the muscular responsiveness to thiazolidinediones might depend on the nature of the muscle type (20). Alternatively, it could be speculated that the physical conditioning of the muscle, which is known to enhance insulin sensitivity, might result in the enhanced expression of PPAR $\gamma$. This hypothesis would be consistent with the higher expression levels of PPAR $\gamma$ mRNA in respiratory muscles, compared with the extremities in these rather hypoactive animals. However, the examination of adult rats having undergone an 8 week exercise program did not reveal any increase in the expression levels of $\operatorname{PPAR} \gamma$ in skeletal or heart muscles.

In conclusion, we have shown that the mRNAs for $\operatorname{PPAR} \alpha$ and PPAR $\gamma$ are most highly expressed in BAT in vivo, with PPAR $\alpha$ being virtually exclusively expressed in BAT and liver. However, $\operatorname{PPAR} \alpha$ is undetectable in brown adipose cells in vitro, suggesting that the expression of this receptor is induced by external stimuli. In addition, the expression of $\mathrm{PPAR} \gamma$ was higher already in WAT from young obese animals compatible with an early adaptive phenomenon. Finally, the presence of PPAR $\gamma$ mRNA is detectable only in particular muscles, such as diaphragm, suggesting the possibility of an influence of fiber type on its expression.

\section{Acknowledgements}

Lean $(F A / f a)$ and obese $(f a / f a)$ male Zucker rats were kindly provided by Dr F Rohner-Jeanrenaud (Laboratoire de Recherches Métaboliques, Université de Genève, Switzerland). The plasmids containing the rat $\operatorname{PPAR} \alpha$ and $\gamma$ cDNAs as well as the L27 sequence (pKS+/ $\operatorname{PPAR} \alpha, \mathrm{pKS}+/ \mathrm{PPAR} \gamma$ and $\mathrm{pKS}+/ \mathrm{L} 27$, respectively) were generously provided by Dr Thomas Lemberger (Institut de Biologie Animale, Université de Lausanne, Switzerland). BRL49653 was a kind gift from S Kliewer (Glaxo Wellcome, USA). The technical assistance of Mme M de Meyer and A Pernin is gratefully acknowledged. We are also thankful to Dr I Cusin for helping with the tissue preparation. This project was supported by grants 3231-51 957.97 and 3200-52 192.97 (to C A Meier), and 3200-037536.93 (to A G Burger).

\section{References}

1 Lemberger T, Desvergne B \& Wahli W. Peroxisome proliferatoractivated receptors: A nuclear receptor signaling pathway in lipid physiology. Annual Review of Cell Biology 199612 335363.

2 Braissant O, Foufelle F, Scotto C, Dauca M \& Wahli W. Differential expression of peroxisome proliferator-activated receptors: tissue distribution of $\operatorname{PPAR} \alpha, \beta$ and $\mathrm{c}$ in the adult rat. Endocrinology $1996137354-366$.

3 Schoonjans K, Staels B \& Auwerx J. The peroxisome proliferator activated receptors (PPARs) and their effects on lipid metabolism and adipocyte differentiation. Biochimica et Biophysica Acta: Lipids and Lipid Metabolism 19961302 93-109.

4 Kliewer SA, Sundseth SS, Jones SA, Brown PJ, Wisely GB, Koble CS et al. Fatty acids and eicosanoids regulate gene expression through direct interactions with peroxisome proliferatoractivated receptors $\alpha$ and $\gamma$. Proceedings of the National Academy of Sciences of the USA $1997944318-4323$.

5 Saltiel AR \& Olefsky JM. Thiazolidinediones in the treatment of insulin resistance and type II diabetes. Diabetes 199645 16611669.

6 Spiegelman BM. PPAR- $\gamma$ : Adipogenic regulator and thiazolidinedione receptor. Diabetes 199847 507-514.

7 Phillips MS, Liu QY, Hammond HA, Dugan V, Hey PJ, Caskey CT et al. Leptin receptor missense mutation in the fatty Zucker rat. Nature Genetics 199613 18-19.

8 Boss O, Samec S, Desplanches D, Mayet M-H, Seydoux J, Muzzin P et al. Effect of endurance training on mRNA expression of 
uncoupling proteins 1, 2 and 3 in the rat. FASEB Journal 199812 335-339.

9 Lemberger T, Staels B, Saladin R, Desvergne B, Auwerx J \& Wahli $W$. Regulation of the peroxisome proliferator-activated receptor alpha gene by glucocorticoids. Journal of Biological Chemistry $199426924527-24530$.

10 Sambrook J, Fritsch EF \& Maniatis T. Molecular Cloning: A Laboratory Manual, edn 2. New York: Cold Spring Harbor Laboratory Press, 1989.

11 Siegrist-Kaiser CA, Pauli V, Juge-Aubry CE, Boss O, Pernin A, Chin WW et al. Direct effects of leptin on brown and white adipose tissue. Journal of Clinical Investigation 19971002858 2864.

12 Champigny O, Holloway BR \& Ricquier D. Regulation of ucp gene expression in brown adipocytes differentiated in primary culture Effects of a new beta-adrenoceptor agonist. Molecular and Cellular Endocrinology 199286 73-82.

13 Deslex S, Negrel R \& Ailhaud G. Development of a chemically defined serum-free medium for differentiation of rat adipose precursor cells. Experimental Cell Research 1987168 15-30.

14 Sears IB, MacGinnitie MA, Kovacs LG \& Graves RA. Differentiation-dependent expression of the brown adipocyte uncoupling protein gene: Regulation by peroxisome proliferator-activated receptor gamma. Molecular and Cellular Biology 199616 34103419.

15 Zennaro MC, Le Menuet D, Viengchareun S, Walker F, Ricquier D \& Lombès M. Hibernoma development in transgenic mice identifies brown adipose tissue as a novel target of aldosterone action. Journal of Clinical Investigation 1998101 1254-1260.

16 Vidal-Puig AJ, Considine RV, Jimenez-Liñan M, Werman A, Pories WJ, Caro JF et al. Peroxisome proliferator-activated receptor gene expression in human tissues - Effects of obesity, weight loss, and regulation by insulin and glucocorticoids. Journal of Clinical Investigation 199799 2416-2422.

17 Lefebvre AM, Laville M, Vega N, Riou JP, Van Gaal L, Auwerx J et al. Depot-specific differences in adipose tissue gene expression in lean and obese subjects. Diabetes 199847 98-103.

18 Auboeuf D, Rieusset J, Fajas L, Vallier P, Frering V, Riou JP et al. Tissue distribution and quantification of the expression of mRNAs of peroxisome proliferator-activated receptors and liver $\mathrm{X}$ receptor- $\alpha$ in humans - No alteration in adipose tissue of obese and NIDDM patients. Diabetes 199746 1319-1327.

19 Vidal-Puig A, Jimenez-Liñan M, Lowell BB, Hamann A, Hu E, Spiegelman B et al. Regulation of PPAR gamma gene expression by nutrition and obesity in rodents. Journal of Clinical Investigation $1996972553-2561$.

20 Burant CF, Sreenan S, Hirano KI, Tai TA, Lohmiller J, Lukens J et al. Troglitazone action is independent of adipose tissue. Journal of Clinical Investigation 1997100 2900-2908.

Received 28 April 1999

Accepted 9 September 1999 